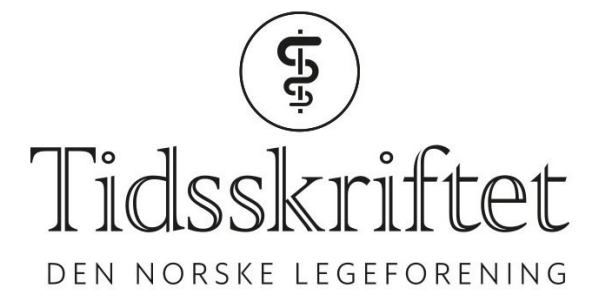

\title{
K.H. Bønaa \& T. Steigen svarer
}

KOMMENTAR

KAARE HARALD BØNAA

E-post: kaare.harald.bonaa@ntnu.no

Kaare Harald Bønaa er overlege ved St. Olavs hospital og professor ved Norges teknisknaturvitenskapelige universitet. Ingen oppgitte interessekonflikter.

\section{TERJE STEIGEN}

Terje Steigen er overlege ved Universitetssykehuset Nord-Norge. Ingen oppgitte interessekonflikter.

Hovedpoenget i vår kronikk er at det ikke er vitenskapelig dokumentasjon for å anbefale koronar angiografi innen 24 timer ved akutt hjerteinfarkt uten ST-elevasjon (NSTEMI). Dette berører ikke Eek og medarbeidere i sin kommentar. De skriver at vi er "uenig» i 24-timers regelen, men vi sier ikke det. Vi sier at den ikke er dokumentert. Kronikken handler om at den faglige listen må plasseres etter grundig vurdering av litteraturen. Det har verken European Society of Cardiology eller ekspertgruppen nedsatt av Norsk Cardiologisk Selskap greid. Vi er overrasket over at Eek og medarbeidere, som utgjorde ekspertgruppen, ikke er opptatt av å gå kritisk inn i litteraturen bak anbefalingene, noe vi gjorde. Ekspertgruppens evaluering gir inntrykk av at den tar lett på kravene til dokumentasjon (1), og kommentaren forsterker inntrykket.

Noen NSTEMI-pasienter har et totalokkludert koronarkar, men dette kan ikke brukes som argument for å angiografere hele NSTEMI-populasjonen innen 24 timer. Litteraturen understøtter ikke dette (2). En generell regel om angiografi innen 24 timer, kan føre til manglende innsats for å identifisere NSTEMI-pasienter som skal håndteres som om de har hjerteinfarkt med ST-elevasjon (STEMI) og angiograferes umiddelbart. Identifisering av disse pasientene krever individuell risikostratifisering basert på klinikk, EKG, og ekkokardiografi. Risikostratifisering er mye viktigere enn å haste alle NSTEMI-pasienter av gårde til angiografi innen 24 timer.

Ekspertgruppen støtter seg på det de omtaler som «trender i internasjonale retningslinjer» i sin argumentasjon. Det er et svakt argument. Historien er full av eksempler på at «internasjonale trender» innen diagnostikk og behandling viste seg å være ineffektiv eller direkte skadelig når de ble testet i randomiserte studier. Og i dette tilfellet er «tidstrenden» ikke entydig. Så sent som i 2017 anbefalte European Acute Care Association koronar angiografi innen 72 timer - ikke 24 timer - ved akutt hjerteinfarkt uten ST-elevasjon (2).

Vi tror alle er enig $i$ at vi må unngå unødig angiografi-ventetid og har aldri argumentert for 4-5 dagers observasjon. Poenget er at med manglende evidens for nytten av angiografi innen 24 timer ved hjerteinfarkt uten ST-elevasjon - unntatt for den gruppen som skal 
håndteres som STEMI - kan resultatet bli at pasienter som er uavklarte og av medisinske grunner bør vente eller ikke angiograferes i det hele tatt, feilaktig sendes til koronar angiografi.

I sin iver etter å være best i klassen, har Eek og medarbeidere kommet i skade for å anbefale en praksis som er faglig og ressursmessig uheldig.

\section{LITTERATUR:}

1. Anfinsen OG, Nerdrum T, Bonarjee V. NCS - kvalitetsutvalget. 2015 ESC guidelines for the management of acute coronary syndromes in patients presenting without persistent ST-segment elevation. Hjerteforum 2016; 29:15-8.

2. Schiele F, Gale CP, Bonnefoy E et al. Quality indicators for acute myocardial infarction: A position paper of the Acute Cardiovascular Care Association. Eur Heart J Acute Cardiovasc Care 2017; 6: 34 - 59. [PubMed][CrossRef]

Publisert: 22. januar 2018. Tidsskr Nor Legeforen. DOI: 10.4045/tidsskr.18.00o4

(C) Tidsskrift for Den norske legeforening 2020. Lastet ned fra tidsskriftet.no 